Doświadczanie śmierci 
Medycyna nosi w sobie przestrzeń dla cudów. Wszyscy na nie czekamy, gdy doświadczy nas groźna choroba. Jeśli wówczas lekarz nie przyda wiary, szukamy jej u uzdrowiciela. Tłum chorych, od tysiącleci, ciśnie się do kogoś w rodzaju Clive’a Harrisa, tłum pogrążony w rozpaczy. „Obok cielesnych przypadłości niesie skrytą skargę niebycia kochanym".

A. Szczeklik, Nieśmiertelność, s. 42-43. 


\section{W POSZUKIWANIU SENSU ŚMIERCI DZIECKA. Z PERSPEKTYWY CHRZEŚCIJAŃSKIEJ}

Problem śmierci dziecka może być analizowany pod wieloma aspektami. Można go badać pod kątem medycznym, zastanawiając się nad przyczyną zgonu. Na śmierć dziecka patrzy się także z perspektywy psychologicznej, badając jego stany emocjonalne $\mathrm{w}$ terminalnej fazie choroby czy podczas samego umierania. Analizuje się też przeżycia psychiczne rodziców związane z fazą umierania dziecka, jego śmierci czy też żałoby.

Szczególnie dramatyczny aspekt śmierci dziecka uwidacznia się wówczas, gdy próbuje się odpowiedzieć na pytanie o jej sens. Medytacja nad śmiercią jest ważnym elementem wielu systemów filozoficznych. Można wręcz powiedzieć, iż przyczyniła się ona do rozwoju myśli filozoficznej. Jednak sam ten rozwój nie doprowadził do całkowitego i pełnego rozwiązania zagadki kresu ludzkiego życia, a szczególnie tajemnicy śmierci dziecka. Sens śmierci może być poszukiwany w oparciu o wysiłek samego rozumu ludzkiego, może też być realizowany w perspektywie religijnej. Praktycznie wszystkie religie podejmują refleksję nad rzeczywistością ludzkiego odchodzenia, przynosząc wyznawcom przynajmniej częściową odpowiedź na pytanie o jej znaczenie, sens czy wartość. Niniejsze rozważania będą próbą spojrzenia na śmierć dziecka z perspektywy chrześcijańskiej. Będzie to pokorna próba rozświetlenia fenomenu odchodzenia dziecka w świetle chrześcijańskiego Objawienia, możliwego do zgłębienia z pomocą rozumu przenikniętego światłem wiary. 
Można zapytać, na ile jest zasadne wyodrębnianie problemu sensu śmierci dziecka z szerokiej problematyki sensu śmierci w ogóle. Przecież pytanie o to, dlaczego umiera dziecko, można sprowadzić do pytania, dlaczego odchodzi człowiek. Jednak w odchodzeniu i śmierci dziecka uwidaczniają się pewne specyficzne aspekty, mniej obecne przy śmierci dorosłego. Po pierwsze, pojęcie „dziecka” zawiera w sobie pewną komponentę czasową. Wskazuje mianowicie na odejście kogoś młodego. Oczywiście dzieckiem jest zarówno istota poczęta, a jeszcze nienarodzona, która umiera czy to wskutek poronienia ${ }^{1}$, czy też $\mathrm{w}$ wyniku aborcji, jak i istota kilku czy nawet kilkunastoletnia, która umiera wskutek choroby lub jakiegoś nieszczęśliwego wypadku. To, co wspólne śmierci osób na tak różnych etapach rozwoju, jak faza prenatalna czy faza dojrzewania, to to, że zaburzona jest naturalna kolejność, a mianowicie, że odchodzi ktoś, kto w naturalny sposób powinien żyć jeszcze wiele lat, że jego śmierć niejednokrotnie wyprzedza śmierć jego przodków - rodziców, a nawet dziadków ${ }^{2}$.

Ostatnie zdanie wskazuje już na kolejny specyficzny aspekt śmierci dziecka. Termin „dziecko” prawie automatycznie niesie ze sobą odniesienie do jego rodziców, co sprawia, że na jego śmierć odruchowo patrzy się z perspektywy jego najbliższych, przede wszystkim rodziców właśnie. $W$ tym sensie o śmierci dziecka będzie mowa także wtedy, gdy umierać będzie na przykład osoba czterdziesto- czy pięćdziesięcioletnia, której rodzice jeszcze żyją. W niniejszych analizach pozostaniemy zasadniczo przy śmierci osoby w bardzo młodym wieku i będziemy na tę śmierć patrzeć także oczami rodziców, nie

${ }^{1}$ Książka I. Barton-Smoczyńskiej O dziecku, które odwróciło się na pięcie (NAF Michał Naftyński, Łomianki 2006), opisująca problematykę żałoby po śmierci dziecka wskutek poronienia, podejmuje także temat sensu śmierci dziecka w punktach: Czy śmierć dziecka może mieć jakikolwiek sens? (s. 169-185) oraz Przestanie dla osób szukających sensu cierpienia po śmierci dziecka (s. 185-186). Wiele zawartych w książce myśli dotyczących śmierci wskutek poronienia można odnieść do śmierci dziecka po jego urodzeniu.

${ }^{2}$ Zaburzenie naturalnej kolejności odchodzenia wyrażające się w śmierci dziecka przed jego przodkami jest czymś oczywistym. Żal po śmierci dziecka jest jakby większy niż przy śmierci dorosłej czy starszej osoby, gdyż ci, którzy pozostają, uświadamiają sobie, że przed dzieckiem życie dopiero się otwierało. Warto jednak zauważyć, iż możliwa jest perspektywa dokładnie odwrotna, związana z inną mentalnością. Z. Kossak w książce Przymierze, przedstawiającej historię Abrahama, ukazuje starożytną mentalność, mocno różniącą się od dzisiejszego sposobu myślenia: „Więcej rozpaczy w rodzinie po śmierci starca niż po śmierci dziecka, gdyż dzieci rodzą się ciągle, a starego już nikt nie zastąpi. Wraz z nim schodzi do grobu cały wiek. Któż by nie żałował bardziej rozłożystego drzewa o tęgich konarach niźli młodej, nikłej płonki?" (Z. Kossak, Przymierze, Instytut Wydawniczy PAX, Warszawa 1957, s. 21). Możliwość istnienia różnych perspektyw myślowych prowadzi do wniosku, iż nie jest chyba uprawnioną próba ważenia, która strata: dziecka, dorosłego czy też starca, jest poważniejsza i boleśniejsza. Jeśli ma się przed oczami prawdę, iż życie ludzkie jest święte od poczęcia i zachowuje swoją godność aż do starości, wówczas rozumie się, iż śmierć każdego człowieka jest (w wymiarze doczesnym) stratą kogoś jedynego i niepowtarzalnego. 
zapominając jednak, że ta niejako zaburzona kolejność śmierci dziecka przed śmiercią rodziców może zdarzyć się także w dorosłym wieku dziecka, które umiera wcześniej niż jego matka czy ojciec.

Wreszcie trzecia specyficzność śmierci dziecka wyraża się w przekonaniu o jego całkowitej niewinności. Ten aspekt także wymaga pewnego doprecyzowania. Jest rzeczą oczywistą, że nawet małe dziecko może popełnić jakieś zło, zaś o niejednym umierającym dorosłym mówi się, że odchodzi człowiek „,́́więty”, , dobry”, ,uczciwy”, który nie niesie w sobie win za grzechy. Wszystko to pokazuje, że „niewinność” nie jest tożsama z „byciem dzieckiem", niemniej jednak można powiedzieć, że im młodsze dziecko odchodzi, tym bardziej niewinność jest jednoznaczna. Mówienie o śmierci dziecka jako śmierci niewinnej osoby zdaje się zakładać, że w przypadku śmierci dorosłego można łatwiej wskazać na zależność między złem, którego się dopuszcza, a jego odejściem. To powiązanie jest niezwykle problematyczne, a wręcz bardzo często nieuprawnione, jednak to ono zdaje się leżeć u podstaw stwierdzeń typu: „przecież to dziecko jest całkowicie niewinne, a musi umierać”.

Można zatem z pewnym uproszczeniem powiedzieć, że specyfiką śmierci dziecka jest to, że - po pierwsze - jest to śmierć w tym sensie nienaturalna, że następując w młodym wieku, zaburza porządek odchodzenia, że - po drugie - jest to śmierć, na którą patrzą rodzice i ich ta śmierć najbardziej dotyka, oraz że - po trzecie - jest to śmierć niewinnej istoty. Te trzy specyficzne aspekty śmierci dziecka należy uwzględnić, podejmując rozważania na temat jej sensu.

\section{Pytanie o zależność między śmiercią dziecka a życiem moralnym osób z jego otoczenia, przede wszystkim rodziców}

Problem budowania relacji między dokonanym złem a cierpieniem i śmiercią stale powraca, nawet w kontekście śmierci niewinnej istoty, jaką jest dziecko. Człowiek za wszelką cenę stara się rozwikłać zagadkę śmierci, jej nielogiczność, szczególnie widoczną w kontekście odchodzenia dziecka. Próba odkrycia zależności między złem a umieraniem jest próbą nadania logiki śmierci. W przy padku dorosłego albo on sam w sobie próbuje odnaleźć zło, którego dokonał, czyniąc z niego moralną przyczynę cierpienia i śmierci, albo też osoby z otoczenia próbują to zrobić, mniej więcej tak, jak działo się to w życiu cierpiącego Hioba, którego przyjaciele przekonywali o jego grzeszności ${ }^{3}$. Wielu rodziców stawia sobie pytanie o to, w czym zawinili, że ich dziecko umarło; śmierć dziecka postrzegają nieraz jako karę

\footnotetext{
${ }^{3}$ Zob. pierwszą zasadniczą część Księgi Hioba: Dyskusja Hioba z przyjaciółmi (Hi 3-28).
} 
za zło. W świetle przekazu biblijnego rzeczywiście cierpienie i śmierć ma przyczynę w moralnej postawie pierwszego człowieka (Rdz 1,16-19). Na bazie tej fundamentalnej prawdy tradycja Starego Testamentu wypracowała zasadę odpłaty ${ }^{4}$, zgodnie z którą uczynione przez człowieka zło ściąga na niego karę Bożą w postaci cierpienia. Jednak z zasadą odpłaty podejmuje polemikę wspomniana Księga Hioba, ukazująca cierpienie człowieka niewinnego.

Jeszcze w Nowym Testamencie myśl o zasadzie odpłaty powraca. Charakterystyczne jest $\mathrm{w}$ tym względzie pytanie, skierowane do Jezusa, a dotyczące niewidomego: „Rabbi, kto zgrzeszył, że się urodził niewidomym - on czy jego rodzice?" (J 9,2). W pytaniu tym widoczne jest odniesienie problemu choroby - niepełnosprawności do życia moralnego samego niepełnosprawnego oraz jego rodziców. Wydaje się, iż także dziś można spotkać osoby, które będą postrzegać śmierć dziecka przez pryzmat życia moralnego, nie tyle jego samego, szczególnie jeśli będzie to małe dziecko, ile jego rodziców. Dodajmy, że w konkretnym przypadku śmierć dziecka rzeczywiście może wynikać z poważnych zaniedbań moralnych rodziców ${ }^{5}$, na przykład, gdy nie dbają o zdrowie dziecka bądź wręcz doprowadzają bezpośrednio do jego śmierci, jak w przypadku aborcji czy dzieciobójstwa. Śmierć jest wówczas skutkiem konkretnego zachowania rodziców.

Odpowiedź Jezusa na pytanie o przyczynę cierpienia jest jednoznaczna: „ani on nie zgrzeszył, ani jego rodzice" (J 9,3). Jezus wyraźnie nie dopuszcza do stworzenia zależności między życiem moralnym dorosłych a niepełnosprawnością niewidomego, rozumianą jako kara Boża. Jest to ważna wskazówka w postrzeganiu śmierci dziecka. Na pewno nie jest ona zesłaną przez Boga na dziecko karą za grzechy rodziców czy otoczenia, choć, jak zostało to powiedziane wyżej, w niektórych przypadkach może być skutkiem moralnie niegodziwego życia dorosłych.

W tym miejscu trzeba wrócić do problemu aborcji i dzieciobójstwa. Dokonanie wielkiego zła, jakim jest aborcja, powoduje śmierć dziecka. Także w tym przypadku nie można mówić, że dziecko jest ukarane za zło w życiu rodziców. Ono jest niewinne. Niemniej jednak wydaje się, że działania aborcyjne wyglądają jak zadanie kary śmierci wobec dziecka, które w opinii dorosłych pojawiło się w niewłaściwym czasie. W przypadku dzieciobójstwa rzecz wygląda podobnie. Oczywiście, za dzieciobójstwo nie zawsze odpowiadają rodzice. Przykładem wyjątkowo wyrazistym jest w tym względzie śmierć dzieci w Betlejem z rąk oprawców Heroda (por. Mt 2,16-18). Okrucień-

\footnotetext{
${ }^{4}$ Por. M. Filipiak, Biblia o człowieku. Zarys antropologii biblijnej Starego Testamentu, Towarzystwo Naukowe Katolickiego Uniwersytetu Lubelskiego, Lublin 1979, s. 146.

${ }^{5}$ Por. R. Plich, Duszpasterz ttumaczy i radzi, [w:] M. Wojaczek (red.), Aniołkowe mamy. Historie kobiet, które poronity. Porady ekspertów, Wydawnictwo M, Kraków 2009, s. 230 i n.
} 
stwo i zaślepienie władcy staje się przyczyną śmierci wielu dzieci, a równocześnie dramatu ich rodziców. W tego typu przypadkach wszechmoc Boga ograniczona jest niejako wolnością człowieka, która to wolność godzi w dobro drugiego człowieka.

Na zależność między śmiercią dziecka a życiem duchowo-moralnym jego otoczenia można także spojrzeć z perspektywy odwrotnej w stosunku do wyżej omawianej. Do tej pory pytaliśmy o to, czy i na ile wcześniejsze (czyli sprzed śmierci dziecka) życie moralne otoczenia ma znaczenie przy odczytywaniu sensu śmierci dziecka. Teraz można postawić pytanie: czy i na ile śmierć dziecka może wpłynąć na dalsze życie duchowo-moralne jego bliskich? Oczywiście, nie ma w tym względzie jednoznacznych odpowiedzi. Życie każdej rodziny, stającej w obliczu śmierci dziecka, będzie odmienne; duchowo-psychiczne przeżycia będą różne. Jedni rzeczywistość odejścia dziecka będą przeżywać bardziej intensywnie i trudno im będzie wrócić do normalnego życia'; inni łatwiej i szybciej pogodzą się ze śmiercią dziecka. Patrząc z pespektywy społeczno-historycznej można na pewno stwierdzić, że intensywność przeżywania śmierci dziecka zwiększyła się wraz z obniżeniem śmiertelności małych dzieci. W epoce, gdy śmiertelność wśród niemowląt była wyższa, ich odejście było traktowane jako coś naturalnego ${ }^{7}$. Wydaje się jednak, że przynajmniej jedno doświadczenie jest wspólne wszystkim ludziom, zarówno współcześnie, jak i w przeszłości: a mianowicie, że po śmierci dziecka postrzeganie rzeczywistości przez jego rodziców na pewno nie jest takie samo, jak przed jego odejściem. Choć po jakimś czasie życie rodziców wraca do pewnej normy, jednak zmienia się (i to na trwałe) perspektywa spojrzenia na życie. Niejednokrotnie ma miejsce przebudowanie hierarchii wartości. Bardzo często nowego znaczenia nabierają wartości duchowe ${ }^{8}$. Nawet w kontekście tak dramatycznej sytuacji, jak śmierć dziecka

${ }^{6}$ O stanach emocjonalnych kobiet, które utraciły dzieci wskutek poronienia, zob. B. Janusz, Psychologiczne aspekty utraty dziecka, [w:] M. Wojaczek (red.), Aniołkowe mamy..., dz. cyt., s. 181-205.

7 Przykładem w tym względzie może być rodzina św. Teresy od Dzieciątka Jezus. Jej rodzice, Zelia i Ludwik (obydwoje ogłoszeni błogosławionymi), mieli w sumie 9 dzieci, spośród których 4 umarło w dzieciństwie (Helena - niewiele ponad 5 lat, Józef Ludwik - niecałe 5 miesięcy, Józef Jan Chrzciciel - 8 miesięcy, Melania - niecałe 2 miesiące). Wydane w formie książki listy rodziców Martin są świadectwem tego, w jaki sposób podchodzili oni do śmierci dzieci. Widoczny jest z jednej strony żal i ból po stracie, z drugiej - pogodzenie się z wolą Bożą. Odczuwa się pewną akceptację śmierci dzieci jako czegoś, co zdarza się w rodzinach nierzadko. Temat śmierci dzieci nie jest zbyt szeroko obecny w bogatej korespondencji bł. Zelii. Zob. Z. i L. Martin, Korespondencja rodzinna 1863-1885, przeł. W. Ryszka, M.J. Jadczyszyn, Wydawnictwo O.O. Karmelitów Bosych, Kraków 2007.

8 „Kobiety widzą pewne korzyści rozwojowe przeżytej strategii, korzyści te są związane ze wzmocnieniem duchowego świata, z refleksją nad sobą i swoim życiem, pogłębieniem światopoglądu, wiary" (I. Barton-Smoczyńska, O dziecku, które..., dz. cyt., s. 174). 
wskutek aborcji i związanego z nim syndromu poaborcyjnego" ${ }^{9}$, może nastąpić przemiana myślenia i odkrycie głębokiej wartości życia, także życia dziecka nienarodzonego ${ }^{10}$.

W tym miejscu warto pochylić się nad możliwymi do zaistnienia relacjom między rodzicami po stracie a Bogiem. $Z$ jednej strony śmierć dziecka może doprowadzić rodziców do utraty wiary. Odejście dziecka rodzi nieraz pytanie o wszechmoc i miłosierdzie Boga. Wątpliwości te mogą doprowadzić albo do całkowitej negacji istnienia Boga, albo do zanegowania jego miłosiernej troski o świat ${ }^{11}$. Z drugiej jednak strony w kontekście śmierci dziecka może nastąpić nowe otwarcie na Boga, dostrzeżenie, że życie dziecka (choć krótkie), było wielkim darem Boga i znakiem Jego miłości ${ }^{12}$. Śmierć dziecka może doprowadzić do rozpalenia nowego entuzjazmu wiary, sprawiając zupełnie nową jakość życia. Nieraz po pewnym czasie rodzice zaczynają rozumieć pewien wymiar sensu śmierci ich dziecka: ono odeszło, aby nasze życie nabrało głębszego wymiaru i aby nasza więź z Bogiem mogła przejść proces pogłębienia ${ }^{13}$.

\section{2. Śmierć dziecka jako ofiara miłości}

Pojęcia takie jak "ofiara” i „ofiarowanie” najczęściej kojarzą się z jakimś negatywnym doznaniem, z doświadczeniem przegranej. Termin ten brzmi religijnie, ale równocześnie obco, szczególnie w świecie, w którym liczą się sukces, powodzenie i pozycja społeczna. Jednak już Viktor Frankl pokazywał, że cierpienie należy powiązać z ofiarą. W cierpieniu bowiem zawsze chodzi o coś, co wykracza poza samo cierpienie. Człowiek winien

9 Problem syndromu poaborcyjnego jest szeroko opisany w książce: J. Dzierżanowski (red.), Psychologiczne następstwa straty dziecka. Przyczyny, leczenie, zapobieganie, Uniwersytet Opolski, Opole 2000.

${ }^{10}$ W taką przemianę wierzył Jan Paweł II, który w encyklice Evangelium vitae (25.03.1995) nr 99 zwrócił się do kobiet, które dokonały aborcji (Jan Paweł II, Evangelium vitae, „Tum”, Wrocław 1995).

11 „I jest rzeczą dobrze znaną, że na gruncie tego pytania dochodzi nie tylko do wielorakich załamań i konfliktów w stosunkach człowieka z Bogiem, ale bywa i tak, że dochodzi do samej negacji Boga. Jeśli bowiem istnienie świata otwiera jakby wzrok duszy ludzkiej na istnienie Boga, na Jego mądrość, wszechmoc i wspaniałość, to zło i cierpienie zdają się zaćmiewać ten obraz - czasem w sposób radykalny, zwłaszcza wobec codziennego dramatu tylu niezawinionych cierpień, a także tylu win, które uchodzą bezkarnie" (Jan Paweł II, List apostolski Salvifici doloris o chrześcijańskim sensie ludzkiego cierpienia, Veritas, London 1984, nr 9).

12 O dwóch możliwych podejściach do problemu wiary w kontekście straty dziecka zob. I. Barton-Smoczyńska, O dziecku, które..., dz. cyt., s. 176.

${ }^{13}$ Książka Angeliki Felki, Naznaczeni Łaską. Jak dostrzec wartość życia po śmierci dziecka (Księgarnia Św. Jacka, Katowice 2012), a szczególnie zawarte w niej wiersze, są świadectwem zmagań o wiarę w kontekście śmierci jej 6-miesięcznej córeczki Hani. 
cierpienie transcendować, to znaczy przekraczać w kierunku jakieś innej wartości, wykraczającej poza samo cierpienie. Frankl dodaje, iż cierpienie można i należy ofiarować ${ }^{4}$. Z takiej perspektywy można patrzeć na śmierć dziecka. Choć taka śmierć zawsze pozostanie niezgłębioną tajemnicą, jednak sama w sobie stanowi wezwanie, aby na niej samej nie zatrzymywać się, aby spojrzeć dalej i głębiej, szukać wartości, na które można ją ukierunkować poprzez akt ofiarowania.

Nie sposób w tym miejscu nie odwołać się do biblijnego wydarzenia, które miało miejsce w życiu patriarchy Abrahama, a które zostało opisane na kartach Księgi Rodzaju. Abraham otrzymuje od Boga obietnicę, że będzie ojcem wielkiego narodu, że jego potomstwo będzie tak liczne, jak gwiazdy na niebie. Syn Izaak rodzi się, gdy jego małżonka Sara i on sam są w podeszłym wieku. Fakt ten odczytują jako wyraźny znak Bożej miłości. Jednak w pewnym momencie Abraham otrzymuje od Boga wezwanie, by złożył swego syna w ofierze. Posłuszny wezwaniu Bożemu udaje się na wzgórze w krainie Moria, by ofiarować syna. Całe to doświadczenie staje się wielką próbą wiary i zaufania Bogu (por. Hbr 11,17n). Księga Rodzaju nie opisuje szczegółowo stanu duchowego, w jakim odbywała się wędrówka na górę Moria. Dla wszystkich pokoleń jest ona jednak symbolem doświadczenia duchowej ciemności, doświadczenia wątpliwości, pytań o Boga, o Jego istnienie, o Jego miłość, o Jego milczenie. Abraham jest jednak gotowy oddać Bogu "to", albo raczej "tego", którego od Boga otrzymał. Podczas wspinaczki na górę Moria na pytanie Izaaka: „Ojcze mój (...) Oto ogień i drwa, a gdzież jest jagnię na całopalenie?” (Rdz 22,7), odpowiada: „Bóg upatrzy sobie jagnię na całopalenie, synu mój" $(\operatorname{Rdz} 22,8)^{15}$. Z jednej strony możemy tę wypowiedź potraktować jako odpowiedź wymijającą, by nie niepokoić syna, z drugiej jednak słowa Abrahama uwidaczniają, że w doświadczeniu ciemności ciągle ufa Bogu, ma Go ciągle przed oczami. Ostatecznie Bóg po-

14 „Moje cierpienie może mieć intencję i mogę cierpieć sensownie tylko wtedy, gdy cierpię za coś lub za kogoś. Toteż cierpienie, jeżeli ma mieć sens, nie może być celem samym w sobie, bo w tym samym momencie cała gotowość cierpienia i gotowość poświęcenia się przemieniłaby się w masochizm. Cierpienie ma sens tylko wówczas, gdy chodzi »o coś«. Akceptując cierpienie, wypełniamy intencją nie tylko samo cierpienie, ale poprzez cierpienie jeszcze coś, co nie jest z nim identyczne - cierpienie transcendujemy. Cierpienie sensowne wskazuje zawsze poza siebie, na coś, o co w cierpieniu chodzi. Jednym słowem, sensowne cierpienie jest przede wszystkim ofiarą" (V.E. Frankl, Homo patiens, przeł. R. Czernecki, Z.J. Jaroszewski, Instytut Wydawniczy PAX, Warszawa 1998, s. 84).

15 Teolodzy zwracają uwagę, iż wyrażenie „Bóg upatrzy sobie” w łacińskich przekładach Pisma Świętego tłumaczone jest jako Deus providebit, co z kolei można przetłumaczyć „Bóg zatroszczy się". Słowa te wyraźniej pokazują, z jakim zawierzeniem Abraham wypowiadał się o Bogu, stale widząc w nim troskliwego Ojca, a nie kogoś, kto bawi się losem człowieka. Por. J. Szymik, Deus providebit. Bóg wobec cierpienia wedtug J. Ratzingera/Benedykta XVI, "Teologia w Polsce" 2011 (5), nr 1, s. 5-22. 
wstrzymuje Abrahama od złożenia ofiary z syna. W zamian ofiaruje baranka, którego odnajduje w zaroślach.

Całe to dramatyczne wydarzenie ukazuje, iż w doświadczeniu śmierci dziecka niezwykle ważna jest perspektywa spojrzenia na całą rzeczywistość. Jeśli $\mathrm{w}$ tym spojrzeniu $\mathrm{w}$ absolutnym centrum pozostanie dziecko, to jego śmierć będzie jawiła się jako coś absurdalnego, bezsensownego, będzie postrzegana jako efekt igraszki losu albo zabawy samego Boga. W tej perspektywie dziecko staje się bożkiem, a Bóg prawdziwy schodzi na dalszy plan albo też jest postawiony w stan oskarżenia. Doświadczenie żalu i bólu po stracie dziecka jest czymś naturalnym, a przede wszystkim jest znakiem wielkiej miłości do dziecka. Jednak dłuższa koncentracja na własnych emocjach, związanych ze stratą dziecka, może być wyrazem egoizmu i przejawem uczynienia z własnego „ja” czegoś w rodzaju bożka. Jeśli w doświadczeniu śmierci dziecka Bóg pozostanie Bogiem, czyli wartością pierwszą i najważniejszą, a na dziecko i jego odejście, a także na własny ból po jego stracie, będzie patrzyło się przez pryzmat Boga, wówczas śmierć dziecka, choć - powiedzmy jeszcze raz - pozostanie tajemnicą (tak jak tajemnicą pozostaną Boże wyroki), to właśnie taka perspektywa może ostatecznie wyzwolić postawę oddania siebie i własnego dziecka Bogu ${ }^{16}$. Zrodzi się postawa ofiarowania, o której mówi Frankl, czyli taka, która poza samą śmiercią dziecka pozwoli zobaczyć inną wartość, na którą człowiek będzie gotów ukierunkować odejście dziecka ${ }^{17}$.

Zanim przyjdzie tu szerzej zatrzymać się nad postawą ofiarowania, trzeba zaznaczyć, że aby do niej doszło, potrzebne są wcześniej: pełna świadomość tego, co się stało, a także umiejętność akceptacji zaistniałej sytuacji. Właściwą bowiem człowiekowi jako świadomemu podmiotowi jest postawa otwarta na poznanie prawdy. Głębokie emocje związane ze stratą dziecka mogą czasem prowadzić do zniekształconego poznania rzeczywistości, wyrażającego się bądź to $w$ negacji faktu śmierci dziecka, bądź to $w$ ucieczce przed rzeczywistością w świat wirtualny lub w świat używek. Rozumowe zmierzenie się z rzeczywistością, prowadzące do pełnego uświadomienia sobie tego,

${ }^{16}$ Odnosząc jeszcze raz problem śmierci do ofiary Abrahama, warto przywołać jeden z komentarzy biblijnych: „w tym opowiadaniu kryje się fundamentalna nauka, że nadzieje, obietnice i plany na przyszłość często są zagrożone i często się nie spełniają. Abraham musi przede wszystkim nieustannie się uczyć, że tylko wiara w Boga jest drogą prowadzącą do dobrobytu i sukcesu" (L. Boadt, Księga Rodzaju, [w:] Międzynarodowy komentarz do Pisma świętego. Komentarz katolicki i ekumeniczny na XXI wiek, VERBINUM, Warszawa 2000, s. 294). Tekst biblijny wzywa zatem do przyjęcia postawy zawierzenia Bogu w kontekście śmierci dziecka.

17 Wspomniana wcześniej Zelia Martin tak opisuje swoje i swojego męża spojrzenie na śmierć córki Heleny: „Ani ja, ani mój mąż nie spodziewaliśmy się tak nagłego odejścia. Kiedy powrócił biedny ojciec i kiedy popatrzył na swoją zmarłą córkę, wybuchnął płaczem i wołał: »Moja mała Helena! Moja mała Helena!«. Potem razem ofiarowaliśmy ją Bogu” (Z. i L. Martin, Korespondencja rodzinna..., dz. cyt., s. 90); „Jestem poddana woli Bożej, choć odczuwam wielki ciężar straty tej kochanej córeczki" (tamże, s. 89). 
co się stało, będzie miało charakter terapeutyczny i będzie ważnym krokiem w stronę zaakceptowania rzeczywistości, czyli zgody woli na to, co się stało. Człowiek współczesny jest istotą niezwykle czynną. Pragnie brać los świata, a tym bardziej własny los, w swoje ręce. Tym bardziej boleśnie doświadcza bezradności wobec umierania i śmierci bliskiej osoby, a szczególnie dziecka. Taka bezradność może prowadzić z jednej strony do rozpaczy, z drugiej jednak - do pokory. Gdy przyjmie człowiek tę drugą postawę, to z jej wnętrza będzie rodzić się, wbrew zewnętrznej bezradności, aktywność woli. To nie jako wynik bezradności czy zniechęcenia, lecz właśnie jako wyraz aktywnej woli, rodzi się postawa akceptacji śmierci. Dzięki temu człowiek rzeczywiście pozostaje istotą aktywną. Pełna świadomość oraz całkowita akceptacja śmierci jest fundamentem dla wspomnianej wyżej postawy ofiarowania dziecka Bogu.

Poprzez ofiarowanie człowiek transcenduje (jak mówi Frankl) śmierć dziecka, przekracza koncentrację myśli, woli i emocji na dziecku, a także na sobie samym, w kierunku samego Boga, któremu oddaje umierające czy już zmarłe dziecko, a także Bogu powierza samego siebie ${ }^{18}$. W przypadku,

18 Przeżycie transcendencji w kontekście śmierci dziecka, szczególnie małego, wyraża się m.in. w mocno obecnym u wielu rodziców przekonaniu, że dziecko po śmierci staje się aniołem; zob. tytuł książki M. Wojaczek (red.), Aniołkowe mamy..., dz. cyt. Stwierdzenie, że dziecko stało się aniołem, wyraża kilka przekonań: po pierwsze, że dziecko znalazło się w rzeczywistości transcendentnej, po drugie, że znalazło się w bliskości Boga, po trzecie, że znalazło się tam jako istotna niewinna, po czwarte, że jest pozbawione cielesności oraz po piąte, że staje się aniołem stróżem swoich bliskich, szczególnie rodziców. Dwa ostatnie przekonania wymagają pewnego wyjaśnienia. Przekonanie o pozbawieniu cielesności jest czymś oczywistym; wyraża ono prawdę o tym, że w śmierci następuje rozpad, całkowita dezintegracja człowieczeństwa, z którego pozostaje osobowe „ja”, nazywane językiem teologicznym duszą nieśmiertelną. Nie można jednak w tym kontekście tracić sprzed oczu prawdy o zmartwychwstaniu ciał na końcu czasu. Dziecko nie staje się po śmierci aniołem w tym sensie, że w czasie ostatecznym przyoblecze się na powrót $\mathrm{w}$ cielesność. Zaś anioł stworzony przez Boga od początku jako istota duchowa, istotą duchową pozostanie na wieczność. W jakim sensie natomiast dziecko staje się aniołem stróżem dla swoich rodziców? Przede wszystkim jest kimś, kto będąc w bliskości Boga, wyprasza potrzebne łaski bliskim. Prawdę tę wyraża Kościól, wierząc w „świętych obcowanie". Osieroceni potwierdzają, że wiele duchowego wsparcia otrzymują od tych, którzy odeszli. Nie jest jednak dziecko aniołem stróżem w sensie dosłownym, tzn. nie zastępuje duchowego posłańca, którego każdy człowiek otrzymuje od Boga. W pobożności angelologicznej mogłyby się pojawić dwie niewłaściwości. Po pierwsze, gdyby kult aniołów został sprowadzony do całkowitej koncentracji na dziecku, czyli gdyby prowadził do „kultu” dziecka, przesłaniającego Boga, co mogłoby się stać wręcz wykroczeniem przeciw pierwszemu przykazaniu Bożemu. Po drugie, gdyby w kulcie aniołów człowiek zatrzymał się na aniołach, i nie oddawałby czci samemu Bogu. Czy ostatnie dwie uwagi czynią kult aniołów czymś podejrzanym? W żadnej mierze. Samo Pismo Święte jest przepełnione obecnością aniołów. Tylko jedno miejsce warto tu przywołać. W historii Abrahama pojawia się tajemnicze opowiadanie o odwiedzinach trzech gości (por. Rdz 18,1-21). Tradycja biblijna nie miała wątpliwości, że to Bóg z dwoma aniołami nawiedził Abrahama. Anioł w Piśmie św. oznacza albo stworzoną przez Boga duchową istotę, która ma określoną misję do wypełnienia, albo samego Boga, który zbliża się do człowieka. 
gdy osobą tą jest matka, chodzi o to, by dokonało się jakby drugie "przecięcie pępowiny". Pierwsze przecięcie - przy porodzie - pozwoliło dziecku funkcjonować poza organizmem matki, natomiast drugie - dokonane przy śmierci dziecka lub też jakiś czas po jego odejściu - sprawi, że matka pozwoli dziecku samodzielnie zaistnieć w rzeczywistości Bożej. Ona sama w sensie emocjonalnym też zacznie funkcjonować niezależnie od zmarłego dziecka. Czasem koncentracja na dziecku po jego śmierci jest wyrazem chęci ocalenia dziecka od zapomnienia. Różnego rodzaju "ocalające od zapomnienia" działania są czymś normalnym i są wyrazem miłości do dziecka, jednak pozostawienie dziecka jedynie we własnej pamięci jest doświadczeniem subiektywnym i mimo starań - ulotnym. Oddanie natomiast dziecka Bogu sprawi, że dalsze istnienie dziecka nie będzie czymś tylko subiektywnym, rozgrywającym się we własnych emocjach i pamięci, ale przybierze charakter obiektywny, niezależny od zacierania się ludzkiej pamięci oraz zmienności ludzkich uczućn ${ }^{19}$.

Gotowość Abrahama ofiarowania Bogu własnego syna nie jest ostatnim słowem Pisma Świętego na temat postawy ofiarowania dziecka. Wszystko to, co wydarzyło się na wzgórzu Moria, jest zapowiedzią dzieła odkupienia dokonanego przez Jezusa Chrystusa ${ }^{20}$. Na paschalne dzieło zbawcze męki, śmierci i zmartwychwstania Jezusa można spojrzeć z perspektywy Boga Ojca oraz z perspektywy Jezusa Chrystusa. Zaangażowanie Boga Ojca wyraża się w słowach z Ewangelii wg św. Jana: „albowiem Bóg tak umiłował świat, że Syna swego Jednorodzonego dał, aby każdy, kto w Niego wierzy nie zginął, ale miał życie wieczne" (J 3,16). Bóg z miłości ofiaruje swego Syna za zbawienie świata. Jest to wyraz najwyższej miłości Boga do świata, do człowieka. W tej ofierze z Syna, złożonej przez Boga Ojca, może uczestniczyć każdy rodzic, włączając swoje umierające czy też już zmarłe dziecko w dzieło zbawiania świata. Dzieło zbawcze dokonało się oczywiście całkowicie i ostatecznie w ofierze Jezusa Chrystusa. Jednak ofiara Chrystusowa zawarła w sobie wszystkie ludzkie cierpienia, umierania i śmierci. Poprzez akt ofia-

Można zatem powiedzieć, iż poprzez kult aniołów, realizowany przez osieroconych rodziców oraz poprzez ich wiarę, że dziecko „żyje pośród aniołów”, przybliża się prawda o samym Bogu, o Jego miłości i opiece. Mądre spojrzenie na anioła będzie zawsze prowadzić do pogłębionej kontemplacji samego Boga. Tak działo się w życiu Maryi, która była otwarta na słowa archanioła Gabriela, a to doprowadziło ją do przyjęcia woli samego Boga, choć była to wola dla niej zupełnie niezrozumiała (por. Łk 1,26-38). Tak też może się dziać i faktycznie dzieje się w życiu duchowym wielu osieroconych.

${ }^{19}$ Zawarte w powyższym tekście przemyślenia pojawiły się po raz pierwszy w kontekście korespondencji mailowej, jaką prowadziłem z Angeliką Felką. Ujrzały one światło dzienne we wspomnianej już wcześniej książce: A. Felka, Naznaczeni Łaska..., dz. cyt., s. 40.

${ }^{20}$ W sposób artystyczny wyraził to Jan Paweł II w Tryptyku Rzymskim (Jan Paweł II, Tryptyk rzymski: medytacje, Wydawnictwo Św. Stanisława BM, Kraków 2003, cz. 3, nr 4). 
rowania zmarłego dziecka Bogu rodzice świadomie i dobrowolnie włączają się w dzieło odkupienia dokonane w ofierze Jezusa Chrystusa ${ }^{21}$.

Patrząc z kolei na paschalne dzieło oczami samego Chrystusa, który jest ofiarą-żertwą, dostrzegamy nowy wymiar śmierci dziecka. Do tej pory na śmierć dziecka patrzyliśmy od strony jego otoczenia, przede wszystkim rodziców. Teraz możemy spojrzeć od strony dziecka, które umiera, które odchodzi. W osobie Jezusa widoczne są wyraźnie wszystkie trzy elementy postawy wobec umierania i śmierci: świadomość (Jezus wie, że Jego droga do Jerozolimy jest drogą ku męczeńskiej śmierci), akceptacja (widoczna przede wszystkim podczas Jego modlitwy w Ogrójcu) oraz wynikające z niej ofiarowanie. Postawa ofiarowania się Jezusa objawia się w wielu miejscach Ewangelii, szczególnie w opisie męki. Benedykt XVI w następujący sposób interpretuje ostanie słowa wypowiedziane przez Jezusa:

(...) według Jana ostatnie słowo Jezusa brzmiało: „Wykonało się!” (19.30). Słowo to (tetélestai) w tekście greckim odsyła do początku Męki, do godziny obmywania nóg; jego opis ewangelista zaczyna od podkreślenia, że Jezus umiłował swoich „do końca” (télos) $(13,1)$. Ten „koniec”, to szczytowe dopełnienie miłości, nastąpił teraz, w momencie śmierci. Jezus rzeczywiście doszedł aż do końca, aż do samej granicy, i ją przekroczył. Urzeczywistnił pełnię miłości - oddał siebie samego ${ }^{22}$.

W te poszczególne elementy postawy Jezusa potrafi włączyć się ciężko chore czy już umierające dziecko, oczywiście adekwatnie do swojego wieku. Na pierwszy rzut oka może wydawać się, iż przyjęcie takich postaw jest niemożliwe w życiu dziecka, że wymagają one niezwykłej dojrzałości. Przyjmowanie ich (czy to wszystkich, czy tylko niektórych) dzieje się w życiu terminalnie chorego dziecka częściej, niż to się wydaje osobom dorosłym ${ }^{23}$. Prostota

21 „Żaden człowiek niczego nie może dodać do dobra Odkupienia. Równocześnie jednak, w tajemnicy Kościoła jako swojego Ciała, Chrystus niejako otworzył własne odkupieńcze cierpienie na każde cierpienie człowieka. O ile człowiek staje się uczestnikiem cierpień Chrystusa - w jakimkolwiek miejscu świata i czasie historii - na swój sposób dopetnia to cierpienie, przez które Chrystus dokonał Odkupienia świata" (Jan Paweł II, List apostolski Salvifici doloris..., dz. cyt., nr 24).

${ }^{22}$ Por. J. Ratzinger - Benedykt XVI, Jezus z Nazaretu. Część II. Od wjazdu do Jerozolimy do zmartwychwstania, Wydawnictwo Jedność, Kielce 2011, s. 238.

${ }^{23}$ Potwierdza to, zajmująca się problemem śmierci dzieci, E. Kübler-Ross m.in. w książce Życiodajna śmierć, przeł. E. Stahre-Godycka, Księgarnia Św. Wojciecha, Poznań 1996, s. 31. Warto na marginesie poczynić pewną uwagę odnośnie do publikacji E. Kübler-Ross. Jej badania naukowe prowadzone $\mathrm{w}$ obszarze psychiczno-duchowych potrzeb ludzi terminalnie chorych (także dzieci) wniosły nieocenionej wartości światło w obszar ludzkiej wiedzy i nauki. Szczególnie chodzi tu o pierwszą książkę Kübler-Ross, Rozmowy o śmierci i umieraniu, wydaną po raz pierwszy w 1969 roku (Media Rodzina, Poznań 1998, tyt. oryg. On Death and Dying). Równocześnie trzeba jednak zaznaczyć, iż wiele szczególnie późniejszych publikacji na temat śmierci nie ma charakteru naukowego. Są one świadectwem synkretyzmu religijno-światopoglądowego, w jakim znalazła się badaczka. Praca magisterska Z. Canibol, Niebezpieczeństwo spirytyzmu we wspótczesnym podejściu do śmierci na przykładzie dziatalności Elizabeth Kübler-Ross, Katowice 2011 (mps), jest rzetelną analizą sygnalizowanego tu problemu. 
myślenia dziecka nie utrudnia, lecz przeciwnie, ułatwia postawę zawierzenia i oddania siebie Bogu, co de facto jest przejawem ofiarowania siebie. Nie na darmo Pan Jezus w swoim nauczaniu dawał przykład dziecka, mówiąc, że „jeśli się nie odmienicie i staniecie jak dzieci, nie wejdziecie do królestwa niebieskiego" (Mt 18,3).

\section{3. Śmierć dziecka - "aby się na nim objawiły sprawy Boże”}

W przywołanym już wcześniej tekście, dotyczącym niewidomego, Jezus po słowach: ",ani on nie zgrzeszył, ani rodzice jego", dodaje: "ale stało się tak, aby się na nim objawiły sprawy Boże" (J 9,3). Te ważne, a zarazem trudne słowa, wymagają głębszego namysłu w kontekście śmierci dziecka. Przede wszystkim należy przypomnieć i podkreślić, że śmierci Bóg nie stworzył (por. Mdr 1,13), gdyż do nieśmiertelności został człowiek powołany (por. Mdr 2,23). Śmierć przyszła na świat przez szatana (por. Mdr 2,24), który sprowadził - za przyzwoleniem ludzkiej woli - zło na świat. Śmierć stała się skutkiem grzechu. Jednak z doświadczenia śmierci Bóg potrafi wydobywać dobro. Ostatecznie Bóg jest Panem, który nad śmiercią włada. Już wskrzeszenie przez Jezusa córki Jaira (por. Mk 5,35-43), a potem wskrzeszenie Łazarza (por. J 11,1-22) jest tego znakiem. Ostatecznie, odkupieńcze dzieło Chrystusa sprawiło, iż śmierć stała się paschą, czyli przejściem ze śmierci do zmartwychwstania. Szczególnie Ewangelia św. Jana, pokazując cały dramat śmierci Jezusa, równocześnie ukazuje ją jako ostateczne wywyższenie Syna Człowieczego.

Jak już to zostało wspomniane, śmierć dziecka może prowadzić do utraty wiary w życiu jego bliskich. Rzeczywiście, odchodzenie dziecka prawie zawsze sprowadza na życie jego bliskich duchowy mrok, czy wręcz nieprzeniknioną noc. Jest to doświadczenie pustki, opuszczenia, braku obecności Boga. Jednak to doświadczenie egzystencjalnej ciemności przekształca się w miejsce szczególnej obecności Boga. Warto w tym miejscu przywołać biblijne znaczenie obłoku. Obłok był znakiem z jednej strony radykalnie przesłaniającym Boga, z drugiej jednak - na obecność Boga wskazywał ${ }^{24}$. W doświadczeniu ciemnej nocy związanej ze stratą dziecka wiele ludzi odnajduje nie tylko obecność Boga, ale zaczyna dostrzegać Jego chwałę.

Odchodzenie dziecka ukazuje względność i kruchość ludzkiego istnienia. Ta nieoczywistość życia człowieka może doprowadzić do medytacji prawdy o tym, że życie jest darem Boga, że każda chwila istnienia ma u podstaw

${ }^{24}$ Por. X. Léon-Dufour, Obłok, [w:] tenże (red.), Stownik teologii biblijnej, Pallottinum, Poznań 1990, s. 589 i n. 
stwórczą miłość Boga. Wartość nawet jednej chwili życia jest widoczna szczególnie wtedy, gdy tych chwil nie ma wiele, wtedy gdy życie okazuje się bardzo krótkie. Życie kończące się w starości zawiera jakąś oczywistość, która może przesłonić prawdę o tym, że ludzkie istnienie zawdzięcza człowiek stałej woli Boga podtrzymywania wszystkiego w istnieniu (creatio continua). Wczesna śmierć łatwiej chyba prowadzi do medytacji Boga jako Stwórcy. Wydaje się, że z mniejszym trudem przychodzi przyjąć prawdę wypowiedzianą przez św. Ireneusza: „chwałą Bożą, żyjący człowiek”.

Śmierć dziecka ochrzczonego nie tylko ukazuje dzieło stworzenia dokonane przez Boga, ale także uwidacznia potęgę dzieła zbawczego dokonanego w Jezusie Chrystusie, w które to dzieło dziecko zostało włączone przez sakrament chrztu świętego. Tak jak w kontekście śmierci dziecka można medytować wielkość dzieła stworzenia, tak też można podjąć kontemplację tego, czym jest chrzest w życiu człowieka. Obdarowanie łaską uświęcającą prowadzi przecież do stworzenia „nowego człowieka” (por. Rz 6,1-14). W tej nowości życia dziecko, umierając, od razu zostaje włączone w pełne szczęście życia wiecznego. Liturgia pogrzebowa dziecka ochrzczonego nie jest de facto modlitwą wstawienniczą za samo dziecko, które przecież jest już zbawione, lecz ma charakter modlitwy dziękczynnej za życie oraz za chrzest, a także jest modlitwą błagalną za bliskich, przede wszystkim za rodziców, aby łaska była dla nich wsparciem w doświadczeniu żałoby i doświadczeniu duchowej ciemności ${ }^{25}$. Wielkość chwały Bożej zawarta w potędze i skuteczności chrztu świętego zdaje się szczególnie objawiać w kontekście śmierci dziecka ochrzczonego.

W tym miejscu rodzi się pytanie o to, czym zatem jest śmierć dziecka, które nie zostało ochrzczone, gdyż nie zdążono tego uczynić, albo też urodziło się martwe lub nastąpiło poronienie. Kościół zachęcając, by nieochrzczone dziecko powierzać miłosierdziu Bożemu, ufa głęboko w zbawienie dzieci, którym

${ }^{25}$ We wprowadzeniu do pogrzebu dziecka ochrzczonego, prowadzący liturgię kapłan wypowiada słowa: „Zmarły(a)... otrzymał(a) chrzest święty i stał(a) się przybranym dzieckiem Bożym. Teraz Bóg wezwał go (ją) do siebie i dał mu (jej) udział w życiu wiecznym. Wierzymy, że modli się on (ona) za swoich rodziców i za nas. Chcemy podziękować Bogu za zbawienie tego dziecka i prosić o pociechę dla rodziców i rodziny oraz o umocnienie naszej wiary" (Obrzędy pogrzebu: dostosowane do zwyczajów diecezji polskich, wyd. 2, Księgarnia Św. Jacka, Katowice 1991, nr 141 A). W podobnym tonie utrzymane są praktycznie wszystkie modlitwy przy pogrzebie dziecka ochrzczonego. Z punktu widzenia prawa kościelnego, formę pogrzebu dzieci ochrzczonych stosuje się w przypadku dziecka, które nie doszło jeszcze do używania rozumu (tamże, nr 136), czyli według prawa kanonicznego chodzi o dzieci do siódmego roku życia; por. KPK 97 § 2. Norma ta wypływa z tego, iż w sytuacji, gdy dziecko już osiągnęło używanie rozumu, wówczas możliwe jest popełnienie przez dziecko grzechu. Dlatego też dla dziecka, które osiągnęło już siódmy rok życia, stosuje się takie obrzędy, jak w przypadku człowieka dorosłego, dla którego wyprasza się w modlitwach błagalnych zbawienie wieczne. 
nie udzielono jeszcze sakramentu chrztu świętego ${ }^{26}$. W nauce chrześcijańskiej istnieje przekonanie, że śmierć następująca w życiu katechumena, czyli osoby dorosłej jeszcze nieochrzczonej, ale już pragnącej chrztu świętego, związana jest z tzw. chrztem pragnienia, który otwiera ją na Bożą łaskę. Można zatem analogicznie pielęgnować nadzieję, że pragnienie ochrzczenia dziecka, które było obecne w sercu rodziców jeszcze przed jego narodzeniem, otwarło dziecko na Bożą łaskę $e^{27}$. Nadzieja na zbawienie dziecka nieochrzczonego wyraża się w liturgii pogrzebu takiego dziecka, które w modlitwach błagalnych zostaje powierzone miłosierdziu Bożemu ${ }^{28}$. W kontekście śmierci dziecka jeszcze nieochrzczonego objawia się rzeczywiście wielkość miłosierdzia Bożego.

\section{Towarzyszenie umierającemu dziecku oraz osieroconym po jego odejściu bliskim - przestrzenią odkrywania sensu śmierci}

Świat ludzkiego cierpienia przywołuje inny świat, świat ludzkiej miłości ${ }^{29}$. Choroba i odchodzenie dziecka przywołuje świat miłości rodziców i jego bliskich. Cierpienie rodziców i bliskich w kontekście odchodzenia dziecka, a potem żałoby po nim - przywołuje miłość, życzliwość i solidarność społeczeństwa oraz wspólnoty Kościoła ${ }^{30}$. Cierpienie w samotności potęguje zarówno samo cierpienie, jak i samotność. Pełne miłości i empatii wsparcie przynosi przynajmniej częściową ulgę w cierpieniu. W doświadczenie bezradności w obliczu odchodzenia i śmierci dziecka wchodzi aktyw-

26 „Jeśli chodzi o dzieci zmarłe bez chrztu, Kościół może tylko polecać je miłosierdziu Boże$\mathrm{mu}$, jak czyni to podczas przeznaczonego dla nich obrzędu pogrzebu. Istotnie, wielkie miłosierdzie Boga, który pragnie, by wszyscy ludzie zostali zbawieni (por. 1 Tm 2,4), i miłość Jezusa do dzieci, która kazała Mu powiedzieć: »Pozwólcie dzieciom przychodzić do Mnie, nie przeszkadzajcie im « (Mk 10,14), pozwalają nam mieć nadzieję, że istnieje jakaś droga zbawienia dla dzieci zmarłych bez chrztu" (KKK 1261). Problem zbawienia dzieci nieochrzczonych został szeroko podjęty w dokumencie Międzynarodowej Komisji Teologicznej (19.01.2001): Nadzieja zbawienia dla dzieci, które umierają bez chrztu, przeł. J. Królikowski, Pallotinum, Poznań 2008.

27 Możliwości przenoszenia kategorii „chrztu pragnienia” z dorosłego katechumena na dziecko nie wyklucza wspomniany wyżej dokument Międzynarodowej Komisji Teologicznej; por. Nadzieja zbawienia dla dzieci..., dz. cyt., nr 94.

${ }^{28}$ We wprowadzeniu do pogrzebu dziecka nieochrzczonego, prowadzący liturgię kapłan wypowiada słowa: „Bóg zna swoje stworzenia od początku ich istnienia i wszystkie ogarnia miłością. Z serdecznym współczuciem będziemy się modlili razem z rodzicami i opłakującymi to dziecko i polecimy je miłosierdziu Jezusa Chrystusa, który umarł za wszystkich ludzi" (Obrzędy pogrzebu..., dz. cyt., nr 141 B).

${ }^{29}$ Por. Jan Paweł II, List apostolski Salvifici doloris..., dz. cyt., nr 29.

30 Artykuł B. Janusza Psychologiczne aspekty utraty dziecka (dz. cyt.) ukazuje elementy wsparcia psychologicznego kobiecie po poronieniu, natomiast artykuł R. Plicha Duszpasterz tłumaczy i radzi (dz. cyt., s. 207-234) wskazuje na ważne aspekty towarzyszenia duszpasterskiego. 
ność miłości. W miejscu, gdzie kończą się możliwości współczesnej medycyny, rozpoczyna się głęboko ludzkie zaangażowanie miłości. Ludzki wymiar miłości uobecniającej się przy śmierci dziecka został potwierdzony i pogłębiony w chrześcijańskim Objawieniu. Na kartach Ewangelii widzimy Jezusa, towarzyszącego rodzicom po stracie dzieci. Tak było zarówno w przypadku Jaira (por. Mk 5,35-43), jak i wdowy z Nain (por. Łk 7,1-10). W tym drugim przypadku cierpienie było podwójne. Wynikało z żałoby po stracie męża oraz z żałoby po śmierci dziecka. Z kolei towarzyszenie ze strony Jezusa Marii i Marcie nie było związane ze śmiercią dziecka, lecz ich dorosłego brata Łazarza, jednak to w tym miejscu Ewangelia podkreśla z jednej strony smutek i żal samego Jezusa po stracie przyjaciela (por. J 11,35), z drugiej - Jego aktywne zaangażowanie $\mathrm{w}$ doświadczenie żałoby przeżywane przez dwie siostry (por. J 11,17-44). Z kolei śmierci Jezusa na krzyżu towarzyszą Jego najbliżsi: Matka Maryja oraz umiłowany uczeń Jan (por. J 19,25-27).

Ze strony współczesnego społeczeństwa osoby, które tracą dziecko, doświadczają pewnego rodzaju izolacji, wynikającej nie tyle ze złej woli, ile raczej z lęku przed tajemnicą śmierci dziecka. Otoczenie nie wie, jak z takimi osobami rozmawiać, jakich użyć słów, by ich nie zranić. $Z$ drugiej jednak strony śmierć dziecka jest miejscem, w którym ludzkie i chrześcijańskie doświadczenie miłości objawia się z niezwykłą intensywnością. Dzieje się to albo ze strony rodziny, albo profesjonalnych wspólnot, takich jak hospicja czy grupy wsparcia, albo też ze strony życzliwych osób, które w zwykłym, w żaden sposób nieprofesjonalnym, ale głęboko ludzkim i chrześcijańskim odruchu, ofiarują pomoc. Pomoc ta może wyrażać się w obecności, w konkretnym wsparciu czy też w oferowaniu własnej modlitwy.

Przestrzeń towarzyszenia w kontekście choroby, śmierci dziecka czy też żałoby po nim na pewno nie jest miejscem moralizowania czy też pouczenia, w jaki sposób należy odczytywać sens śmierci dziecka. Majestat śmierci dziecka jest wezwaniem do pokornego, wspólnego poszukiwania prawdy o sensie życia, cierpienia i śmierci. W towarzyszeniu tym chodzi nie tyle o to, by palcem wskazywać dokąd ma podążać na przykład rodzic przeżywający żałobę, ile raczej o to, by razem z nim przejść drogę ku prawdzie, ku sensowi, ku miłosiernemu Bogu. Odkrywanie sensu dokonuje się stopniowo, etapami, i jego przebieg zależy od wielu czynników: od etapu żałoby, od konstrukcji psychiczno-emocjonalnej, od głębokości wiary. Potrzebna jest zatem wielka cierpliwość, pokora, empatia, wypływające z ludzkiej i chrześcijańskiej nadziei. Jedna rzecz wszakże jest pewna: nigdy do końca nie będzie można zgłębić problemu śmierci dziecka. W ziemskim wymiarze pozostanie ona do końca tajemnicą. I choć może z biegiem czasu pewien wymiar sensu odejścia dziecka ukaże się, jednak będzie to zaledwie mała cząstka wielkiego misterium śmierci dziecka. 
Tekst artykułu skonsultowałem z rodzicami, doświadczonymi stratą dzieci. Poniżej zamieszczam fragmenty ich opinii. Pierwsza została wyrażona przez Joannę Plutę, która wraz z mężem Przemysławem pod koniec października 2012 roku pożegnała swojego syna Alka. Alek nie ukończywszy jeszcze 5 lat odszedł do wieczności, po 2,5 latach walki z chorobą nowotworową:

Artykuł oddaje większość zagadnień związanych z tematem. Wiele zdań, dosłownie, wyraża mnie samą. Są fragmenty tekstu, szczególnie o dojrzewaniu dzieci do odejścia, które wyciskały mi łzy, bo taka właśnie jest prawda. My na szczęście dostrzegliśmy to w każdym momencie życia Alka. Rzeczywiście, dziecko dojrzewa do śmierci. Ma ogromną świadomość. Dodałabym, że ono nas uczy i przygotowuje na swoje odejście. Tylko trzeba umieć to zobaczyć. Zgadzam się, że były momenty, gdy zastanawialiśmy się z Przemkiem, w czym my zawiniliśmy, przy czym było to na etapie choroby syna, a nie po śmierci. Brakuje mi w tekście trochę o sferze aniołów. Każdy przecież wierzy, że nasze dzieci to osobiści Aniołowie Stróżowie. Informacje zawarte w artykule powinni otrzymywać osieroceni od każdego księdza. Gdybym mogła udostępniać tekst innym rodzicom i bliskim dzieciom osobom, to byłoby miło. Proszę tylko o zgodę. Wielu osobom pomogłoby to $\mathrm{w}$ uporządkowaniu swoich myśli, przynajmniej w jakimś stopniu. Tekst ma moją akceptację.

Pragnę zaznaczyć, iż przypis 18, nieobecny w pierwszej wersji tekstu, został przeze mnie dopisany w kontekście słusznej uwagi poczynionej przez Joannę.

Druga opinia pochodzi od Angeliki Felki, która w maju 2010 roku wraz z mężem Darkiem pożegnała 6-miesięczną córeczkę Hanię. Hania zmarła po ciężkiej, trwającej 3 miesiące chorobie nowotworowej. Jest autorką przywoływanej w tekście książki Naznaczeni Łaską. Jak dostrzec wartość życia po śmierci dziecka ${ }^{31}$ :

Pełne bogactwo przeżyć i doznań, jakiego doświadczają rodzice po śmierci małego dziecka, zostały poruszone w artykule. Wraz z mężem dane nam było przez to przejść. Czymś, co można by dodać jest to, że także pozostali członkowie rodziny dotyka tak horrendalnie trudne doświadczenie. Mam tu na myśli rodzeństwo zmarłego dziecka. Dla nich (szczególnie dla młodszych dzieci) ta sytuacja wydaje się być czymś kompletnie nowym i niezrozumiałym. Dotychczasowe życie ulega jakby wywróceniu, szczególnie wtedy, kiedy rodzice intensywnie przeżywają bolesną stratę. Co więcej, niektórzy mogą nawet mieć problem z zaakceptowaniem faktu istnienia pozostałych dzieci, mogą tak bardzo skupiać się na tym dziecku, które odeszło. Ważne, aby ono nie odebrało i przysłoniło potrzeb emocjonalnych i miłości tych dzieci, które pozostały przy rodzicach. Taka sytuacja to „próba ogniowa” nie tylko dla samych małżonków (niektóre związki rozpadają się, szczególnie jeśli małżonkowie nie potrafią odnaleźć się $\mathrm{w}$ tej sytuacji, albo zupełnie inaczej radzą sobie z przeżywaniem żałoby), ale też dla całej rodziny. Wszyscy członkowie rodziny muszą stawić czoła temu doświadczeniu, muszą starać się wyjść z tego obronną ręką. Co ważniejsze, może nawet uda im się wydobyć z tego nieszczęścia jakieś dobre, pozytywne wartości. Dla wierzących wystarczającą motywacją może być pragnienie spotkania zmarłego dziecka tam,

31 A. Felka, Naznaczeni Łaską..., dz. cyt. 
gdzie ono już przebywa. W Wieczności, w Niebie. A przez to nieustanne starania, aby być kimś dobrym, lepszym. Samo zrozumienie pojęcia istnienia „Nieba” w kontekście odejścia dziecka wydaje się być sprawą kluczową. Ja również borykałam się z trudnością ogarnięcia rozumem tego zagadnienia, pytałam o to, poszukiwałam odpowiedzi. Dużo czasu upłynęło, zanim to przepracowałam i ugruntowałam swoje myślenie. Reasumując, wszystkie opisane aspekty, które dotyczą śmierci małego dziecka, są mi bliskie. To tak, jakbym czytała o moim własnym doświadczeniu, o przeżyciach, które dotknęły moją rodzinę.

\section{In search of the meaning of a child's death from a Christian perspective}

\section{Sum mary}

Death is an unusual mystery and the death of a child is an especially unusual mystery. Such death violates the natural chronology of events as it makes someone completely innocent and defenseless pass away and deeply affects family relationships. This article does not have the ambition to unravel the great mystery of human existence, but it only attempts to deal with some of its aspects at the philosophical and theological level. It points out that there is no simple relationship between the death of a child and a moral life, especially that of parents'. To look for such a relationship as a justification of a child's death would be unfair. When it comes to relationships with God, on the one hand, the death of a child may cause parents to remove God from their lives and even to deny His existence; on the other hand, an attempt to accept the death of a child may be understood as a sacrifice offered to God. Such death becomes a privileged space for experiencing the profound effects of God's grace and mercy, and it brings about a deeply human attitude, first, to a dying child, and then to those who have been left with a void after their child's death. In this way, it deepens interpersonal relationships. 
